\title{
THE STUDY OF THE ROLE OF BIOLOGICAL IRON SULFIDE COMPOSITES ON COPPER REMOVAL BY CHANGING GEOCHEMICAL FORMS
}

\author{
Yajie LIANG ${ }^{1,2,3}$, Shuhuan LAN ${ }^{1,2,3}$, Yifei XIE ${ }^{1,2,3}$, Xiang XIA ${ }^{1,2,3}$, Xudong LI ${ }^{1,2,3 *}$, Peihan YAN ${ }^{1,2,3}$, \\ Yansu WANG ${ }^{1,2,3}$ and Wei YUAN ${ }^{1,2,3}$
}

${ }^{1}$ Key Laboratory of Environmental and Applied Microbiology, Chengdu Institute of Biology, Chinese Academy of Sciences, 610041, Chengdu, PR China

${ }^{2}$ Environmental Microbiology Key Laboratory of Sichuan Province, Chengdu Institute of Biology, Chinese Academy of Sciences, 610041, Chengdu, PR China

${ }^{3}$ University of Chinese Academy of Sciences, 100049, Beijing, PR China

*Corresponding author: lixd@cib.ac.cn

(Received May 2018; accepted July 2018)

Key words: sulfate reducing bacteria, BCR, bacterial community

\begin{abstract}
The growth of biological iron sulfide composites and their efficacy for changing the geochemical forms of copper in sediment have been investigated. The role of bacteria in copper removal was identified using copper concentrations in three forms extracted via three sequential extraction methods. Furthermore, bacterial community diversity was investigated between different treatments. Copper was transformed from the weak acidic extraction state to the reduction state and the oxidation state under the action of biological iron sulfide composites. The conversion rates of copper from the weak acidic extraction state to other states was up to $76.66 \%$ and the increasing rates of the reduction state was up to $177.85 \%$. Higher dissolved oxygen does harm sulfate reducing bacteria and results in low removal efficiency of copper. It can be inferred that differences in the bacterial community structure resulted in differences between conversion rates and biological efficacy through the correlation between copper concentration and alpha diversity or beta diversity. Furthermore, bacterial 16S rRNA gene analysis showed that Proteobacteria, which sulfate reducing bacteria belong to, were predominant in the group with higher removal efficiency. The biological iron sulfide composites affected the removal efficiency of copper by increasing the sulfate reducing bacteria activity inside the sediments.
\end{abstract}

Palabras clave: bacterias reductoras de sulfato, BCR, comunidades bacterianas

\section{RESUMEN}

Se investigó el crecimiento de compuestos biológicos de sulfuro de hierro y su eficacia para cambiar las formas geoquímicas del cobre en sedimentos. El papel de las bacterias en la remoción del cobre se identificó utilizando concentraciones de este metal en tres formas obtenidas por métodos de extracción secuenciales. Asimismo, se investigó la diversidad de las comunidades bacterianas en los diferentes tratamientos. El cobre se transformó del estado de extracción ácido débil a los estados de oxidación y reducción bajo la acción de los compuestos biológicos de sulfuro de hierro. La tasa de conversión del hierro del estado ácido débil a los otros estados llegó al 77.66 \% y las tasas de 
incremento del estado de reducción llegaron hasta el $177.85 \%$. El oxígeno disuelto en concentraciones elevadas daña a las bacterias reductoras de sulfato reduciendo su eficiencia en la remoción del cobre. Por medio de la correlación entre las concentraciones de cobre y la diversidad alfa o beta se pudo inferir que las diferencias en la estructura de las comunidades bacterianas resultan en diferencias en las tasas de conversión y en la eficacia biológica. Aún más, el análisis genético del ARNr 16S bacteriano mostró que las Protobacteria, a las que las bacterias reductoras de sulfato pertenecen, fueron predominantes en el grupo con la eficacia de remoción más elevada. Los compuestos reductores de sulfuro de hierro afectan la eficacia de la remoción del cobre al incrementar la actividad de las bacterias reductoras de sulfato dentro de los sedimentos.

\section{INTRODUCTION}

Heavy metal pollution has developed into a severe environmental problem. It has been estimated that approximately $19,300 \mathrm{~km}$ of streams and $72,000 \mathrm{hm}^{2}$ of lakes and reservoirs have been damaged seriously by heavy metals (Johnson and Hallberg 2005, Rahman et al. 2017). The excessive and accidental emissions of heavy metals from metallurgy, mining, electroplating, and other industries would do harm to the human body and the environment. Heavy metals with various geochemical forms could be continuously accumulated and migrated which could cause permanent damage to the environment ultimately. Especially, intake of excessively large doses of copper may lead to mucosal irritation and corrosion, liver and kidney damage, even chronic copper poisoning, result in brain damage. Generally, applicable methods to remove heavy metals are chemical precipitation, the physical-chemical process, and biological treatment (San and Donmez 2012, Samad et al. 2017). Although heavy metals are generally deposited in river sediments and the water quality is improved to meet drinking water standards by chemical precipitation and physical-chemical process, the water is still at a great risk of being secondary polluted (Ong et al. 2005, Crini 2006, Ebrahimi et al. 2017). And the overall cost could not be lowed obviously, and regeneration could not be solved effectively. Noteworthily, biological treatment can reduce the risk of recontamination effectively and is benefit for subsequent ecological restoration. In our study, microbiological methods were used to remove copper to reduce environmental damage.

The BCR three-step sequential extraction method (formulated by the European Communities Bureau of Reference) listed four states of heavy metals corresponding to their decreasing biological activity: weak acidic extraction state, reduction state, oxidation state, and residue (Wen et al. 2016, Arshadullah et al. 2017, Afzal et al. 2018, Khan et al. 2018). Microorganisms play an essential role in this transformative process though it is mainly via mineralization. Thereinto, sulfate reducing bacteria (SRB) as a general term for all prokaryotes with the ability to reduce sulfate, are widely found in various ecological environment (Angermeyer et al. 2016, Pelikan et al. 2016). SRB are involved in various biochemical reactions in the natural environment, including organic degradation, metal ion reduction, and the biological treatment of chlorine compounds (Ucar et al. 2011, Abija and Nwankwoala 2018). The capacity of SRB to generate $\mathrm{H}_{2} \mathrm{~S}$ which precipitates the metal as sulfides can help to prevent secondary pollution because of the non-water-soluble substances (Costa et al. 2007, Pol et al. 2001, Nawaz et al. 2018). Therefore, SRB have already become an effective method for biologically repairing various heavy metal contaminated wastewaters (Hanna Jaworowska-Deptuch 2011, Ucar et al. 2011). A previous study proves SRB can generate nano-grade sulfur compounds in situ and form biological iron sulfide composites(BISC) that have outstanding treatment effect on $\mathrm{Cu}^{2+}$ removal. Yang et al. (2014) finds that the maximum removal efficiency of the composites for $\mathrm{Cu}^{2+}$ was to $77.12 \%$ after 16 days of cultivation. The result of other studies was consistent with that result and showed there were about $77 \%-98 \%$ removal rate of $\mathrm{Cu}^{2+}$ in wastewater (Gao et al. 2017, Guerrini et al. 2018, Deptuch et al. 2011, Lu et al. 2018). On the other hand, SRB are anaerobic microbes and have different vertical distributions at different depths (Jiang et al. 2009, Kondo et al. 2012, He et al. 2015, Hausmann et al. 2016, Mogensen et al. 2005, Gu and Zhang 2018). Therefore, it can be speculated that SRB are able to migrate heavy metal to the bottom from upper layer of the sediment which can reduce the possibility of secondary pollution of rivers and lakes.

However, few researches have done research on sediment that are polluted by copper. The answers about how SRB change copper geochemistry form or remove the copper or how the composition of SRB changes in $\mathrm{Cu}^{2+}$ removal process is not clear. 
Therefore, in this study, we designed a testing apparatus to explore 1) the removal of $\mathrm{Cu}^{2+}$ in copper pollution sediment by BISC, 2) the changes of bacterial community composition after adding biological iron sulfide composites in $\mathrm{Cu}^{2+}$ removal process.

\section{MATERIALS AND METHODS}

\section{Conditions for biological iron sulfide composites}

A strain of SRB was isolated from black smelly sediment and named SRB525. The composition of its growth liquid medium as the following (in $\mathrm{g} / \mathrm{L}$ ): $\mathrm{KH}_{2} \mathrm{PO}_{4}, 0.5 ; \mathrm{NH}_{4} \mathrm{Cl}, 1.0 ; \mathrm{CaCl}_{2} \cdot 2 \mathrm{H}_{2} \mathrm{O}, 0.1 ; \mathrm{NaCl}$, $1.0 ; \mathrm{MgSO}_{4} \cdot 7 \mathrm{H}_{2} \mathrm{O}, 2.0$; sodium lactate, 25.0 ; yeast extract, 5.0. Reducing-agent supplement consisted of $15 \mathrm{~g} \mathrm{FeSO}_{4} \cdot 7 \mathrm{H}_{2} \mathrm{O}, 0.1 \mathrm{~g}$ of ascorbic acid and $0.1 \mathrm{~g}$ of sodium thioglycolate was added into the culture medium through a $0.22 \mu \mathrm{m}$ sterile filter after sterilization at $121^{\circ} \mathrm{C}$ for $20 \mathrm{~min}$. The final $\mathrm{pH}$ was adjusted to 8.0 via $1 \mathrm{~mol} / \mathrm{L} \mathrm{NaOH}$ (Li et al. 1994, Xie et al. 2013).

BISC would be generated after 12days' culture of SRB in anaerobic environment at $30^{\circ} \mathrm{C}$ in an anaerobic tank (BacBasic, ShelLab). At the bottom of the bottle, there was a layer of black precipitate with metallic luster, which were what we called biological iron sulfide composites. Typically, the sulfide concentration was used as the marker of biological iron sulfide composites. Here, the sulfide concentration was $1264.6 \mathrm{mg} / \mathrm{L}$.

\section{Experiment equipment design}

The sediment used for experiment originated from the Fu Nan River, Cheng Du, Sichuan Province, China and had been aerated for a week to remove all organic matter from $237 \mathrm{~g} / \mathrm{L}$ to $65 \mathrm{~g} / \mathrm{L}$ ) as well as sulfides. Then, the sediment was put on the bottom of a hardly flat tube. A rubber plug with air vent was installed at the top of the tube. The concentration of $\mathrm{Cu}^{2+}$ was added to $70 \mathrm{mg} / \mathrm{kg}$ (the background value was about $25-30 \mathrm{mg} / \mathrm{kg}$ ), and biological iron sulfide composites with copper sulfide of the same molarity were added into half of the prepared types of experiment equipment. The experiment included two further types of equipment with aeration and the other two without aeration (referred as settled samples in this paper). Each equipment had three replicated experiments. Aeration aimed to change dissolved oxygen in the water to study whether oxygen would affect the copper removal efficiency of biological iron sulfide composites. Therefore, four different treatments were prepared to study the effect of BISC and DO. Each experimental setup was sterilized except for biological iron sulfide composites.
Two months later, one part of samples was stored at $-20{ }^{\circ} \mathrm{C}$ for the follow-up experiment, and the other part was immediately used for the next experiment.

\section{Determination of copper concentration}

Three repetitions in each equipment type was obtained from the lower-middle part of the hardly flat tube. The samples were dried and filtered with 100 mesh sieve before copper concentration measurement. Depending on the prevailing chemical and geological conditions, heavy metals can be partitioned into different chemical forms, which are associated with a variety of organic and inorganic phases. The copper concentration was measured via the BCR three-step sequential extraction method, which contained a weak acidic extraction state, a reduction state, and an oxidation state (referred to as BCR1, BCR2, BCR3, respectively). Furthermore, the total copper concentration was measured via microwave digestion (referred to as the total). Copper extracted from the sediment was measured via graphite furnace atomic absorption (GFAAS, RayLeigh).

\section{DNA extraction and MiSeq sequencing of $16 \mathrm{~S}$ rRNA gene amplicons}

DNA was extracted using the MO BIO Power Soil DNA Extraction kit(MO BIO Laboratories, Carlsbad, CA, USA). DNA concentration and quality were checked using a NanoDrop Spectrophotometer. The extracted DNA was diluted to $10 \mathrm{ng} / \mu \mathrm{L}$ and stored at $-40{ }^{\circ} \mathrm{C}$ for further use.

The universal primers $515 \mathrm{~F}$ (5'-GTGCCAGCMGCCGCGGTAA-3') and 909R (5'-CCCCGYCAATTCMTTTRAGT-3') with 12 nt unique barcodes were used to amplify the V4 hypervariable region of the 16S rRNA gene for pyrosequencing using Miseq sequencer (Caporaso et al. 2012). The PCR mixture $(25 \mathrm{ml})$ contained $1 \mathrm{x}$ PCR buffer, $1.5 \mathrm{mmol} / \mathrm{L} \mathrm{MgCl}_{2}$, each of the deoxynucleoside triphosphate at $0.4 \mathrm{mmol} / \mathrm{L}$, each primer at 1.0 $\mathrm{mmol} / \mathrm{L}, 0.5 \mathrm{U}$ of Ex Taq (TaKaRa, Dalian), and $10 \mathrm{ng}$ soil genomic DNA. The PCR amplification program included initial denaturation at $94{ }^{\circ} \mathrm{C}$ for $3 \mathrm{~min}$, followed by 30 cycles of $94^{\circ} \mathrm{C}$ for $40 \mathrm{~s}, 56^{\circ} \mathrm{C}$ for $60 \mathrm{~s}$, and $72{ }^{\circ} \mathrm{C}$ for $60 \mathrm{~s}$, and a final extension at $72{ }^{\circ} \mathrm{C}$ for $10 \mathrm{~min}$. Two PCR reactions were conducted per sample and both were combined after PCR amplification. PCR products were subjected to electrophoresis using $1.0 \%$ agarose gel. The band with a correct size was excised and purified using SanPrep DNA Gel Extraction Kit (Sangon Biotech, China, Cat\# SK8132) and then quantified with Nanodrop. All samples were pooled together with equal molar 
amount from each sample. The sequencing samples were prepared using TruSeq DNA kit according to manufacturer's instructions. The purified library was diluted, denatured, re-diluted, mixed with PhiX (equal to $30 \%$ of final DNA amount) as described in the Illumina library preparation protocols, and then applied to an Illumina Miseq system for sequencing with the Reagent Kit v2 $2 \times 250 \mathrm{bp}$ as described in the manufacturer's instructions.

\section{Pyrosequence data analysis}

The sequence data were processed using QIIME Pipeline-Version 1.7.0 (http://qiime.org/). All sequence reads were trimmed and assigned to each sample based on their barcodes. Sequences with high quality (lengths $>150 \mathrm{bp}$, without ambiguous base ' $\mathrm{N}$ ', and with average base quality score $>30$ ) were used for downstream analysis. Sequences were clustered into operational taxonomic units (OTUs) according to a $97 \%$ identity threshold. The aligned ITS gene sequences were used for chimera check using the Uchime algorithm (Edgar et al. 2011). All the samples were randomly re-sampled to 11,478 reads. We calculated the alpha-diversity (phylogenetic distance whole tree, chaol estimator of richness, observed species, and Shannon's diversity index) and beta-diversity (PCoA, UniFrac) analyses. For these, the rarefaction curves were generated from the observed species. Taxonomy was assigned using the Ribosomal Database Project classifier (Wang et al. 2007).

\section{RESULTS}

\section{The removal efficiency of $\mathrm{Cu}^{2+}$ by BISC}

Water-soluble copper was got via the BCR threestep sequential extraction method and microwave digestion (Table I). To obtain the differences between original samples and treated samples, the percentages of their composition at three states were compared (Fig. 1).

According to the principles of the BCR three-step sequential extraction method, samples that are easier to extract will be less stable, while samples that are more difficult to extract will be more stable. The obtained order of stability from more to less stable was from BCR1 to BCR3. In the sediment, the form that can be absorbed by plant mainly has a weak acidic extraction state. As the state becomes more stable, the more difficult it also becomes to combine the heavy metal with the organism (Xian 1987). Therefore, it could be inferred that biological effective content in settled samples was lower than in aeration samples, which meant that it was less toxic for the organism. Compared to the control groups, the percentage of BCR1 in the test groups was lower than that in the control groups, while the percentage of BCR2 was higher than that in the control groups, and the percentage content of BCR3 did not change significantly. The conversion rates from BCR1 to other states of BA, BS, SA, SS were 50.78\%, 68.37\%, 59.79\% and $76.66 \%$, while the increasing rates of BCR2 were $86.38 \%, 113.23 \%, 136.87 \%$ and $177.85 \%$, respectively. This suggested that after BISC addition, copper had been transformed from BCR1 to BCR2, the stability of copper had been increased, and the biological effectiveness in the system had overall decreased, indicating that SRB was beneficial for copper repair. SRB produced $\mathrm{S}^{2-}$ during metabolic processes, and $\mathrm{S}^{2-}$ could generate metal sulfide with copper, which belong to a reduction state and were very stable. Therefore, these were not easier to combine with organisms, compared to copper chemical treatment, which significantly reduced the possibility of secondary pollution. The percentage of BCR1 in the aeration groups was higher than in the settled groups, and the percentage of BCR2 was lower than in the settled groups, suggesting that aeration did not

TABLE I. CONCENTRATION OF COPPER IN DIFFERENT STATES OF SAMPLES (mg/kg)

\begin{tabular}{llccccc}
\hline Date & Conc. & BCR1 & BCR2 & BCR3 & SUM & Total \\
\hline \multirow{6}{*}{$1 \mathrm{~d}$} & BA & $41.06 \pm 0.30$ & $7.59 \pm 0.33$ & $5.00 \pm 0.22$ & $53.65 \pm 0.63$ & $66.21 \pm 0.23$ \\
& BS & $39.15 \pm 0.60$ & $9.71 \pm 0.42$ & $4.86 \pm 0.21$ & $56.72 \pm 0.89$ & $71.15 \pm 0.66$ \\
& SA & $40.18 \pm 0.20$ & $8.62 \pm 0.38$ & $6.43 \pm 0.28$ & $55.23 \pm 0.71$ & $69.94 \pm 0.81$ \\
& SS & $39.95 \pm 0.36$ & $9.34 \pm 0.41$ & $5.57 \pm 0.24$ & $54.86 \pm 0.99$ & $68.44 \pm 0.68$ \\
\hline \multirow{6}{*}{$60 \mathrm{~d}$} & BA & $20.21 \pm 0.51$ & $14.14 \pm 0.57$ & $20.87 \pm 0.46$ & $55.22 \pm 0.34$ & $64.01 \pm 0.12$ \\
& BS & $12.38 \pm 0.88$ & $20.70 \pm 0.40$ & $21.78 \pm 0.38$ & $54.86 \pm 0.16$ & $67.77 \pm 0.47$ \\
& SA & $16.16 \pm 0.54$ & $20.42 \pm 0.21$ & $17.72 \pm 0.08$ & $54.30 \pm 0.67$ & $61.72 \pm 0.64$ \\
& SS & $9.32 \pm 0.74$ & $25.95 \pm 0.62$ & $20.00 \pm 0.21$ & $55.28 \pm 0.67$ & $70.35 \pm 0.59$ \\
\hline
\end{tabular}



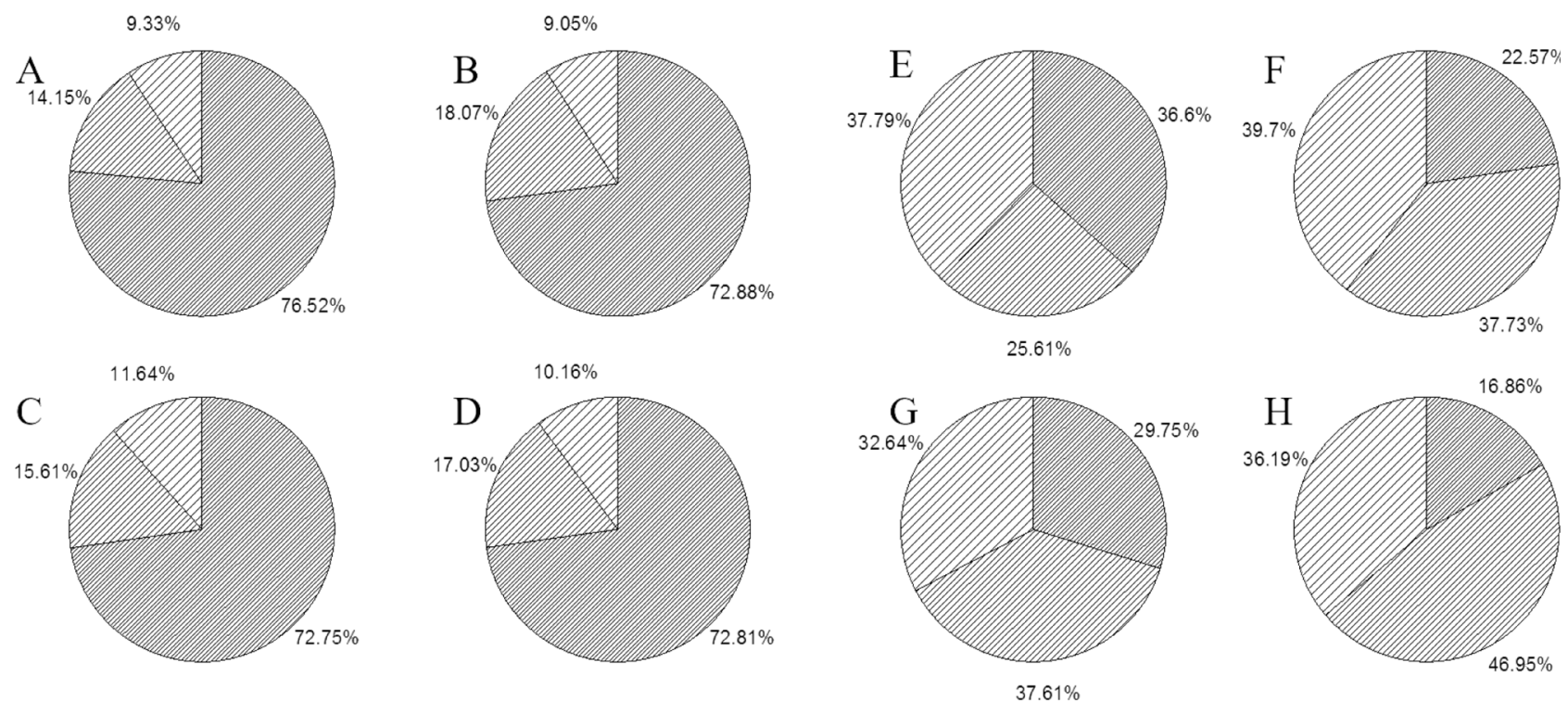

NIIIA BCR1 UIIIA BCR2 ZI/A BCR3

Fig. 1. Percentage composition of three states extracted via the BCR three-step sequential extraction method of original samples and treated samples. A, B, C, D refers to BA, BS, SA, SS of original samples; E, F, G, H refers to BA, BS, SA, SS of treated samples. $\mathrm{BA}$ refers to the sample without BISC and with aeration; BS refers to the sample without BISC and without aeration; SA refers to the sample with BISC and with aeration; SS refers to the sample with BISC and without aeration

aid BISC to deal with copper. This might be because aeration increased dissolved oxygen in the water, thus changing the stable flora relationship between SRB and other aerobic bacteria. This in turn resulted in a decline of SRB activity result in a decreased treatment effect of copper (Jalali 2000).

\section{The change of bacterial taxonomy composition after BISC addition}

The extracted DNA of the test was taxised through RPD. The bacterial community diversity at the phylum level was analyzed (Fig. 2).

Fig. 2 showed all samples were dominated by Proteobacteria, and the relative abundances of these were $51.24 \%, 59.16 \%, 73.87 \%$ and $84.51 \%$, respectively. The next dominant bacteria were Firmicutes, and the relative abundances of these were $13.98 \%, 20.57 \%, 10.89 \%$ and $9.86 \%$, respectively. As we know, Proteobacteria is the biggest bacterial phylum. Most SRB belong to Proteobacteria, while others belongs to Firmicutes. After addition of BISC, the relative abundance of Proteobacteria increased by about $20 \%$. In the aeration condition, the relative abundance of Proteobacteria decreased by about $8 \%$. It indicated that after adding BISC to the equipment, the relative abundances of Proteobacteria and Firmicutes increased, meanwhile, the removal rates of copper also increased, so it could be inferred that BISC addition might increase the removal rates of copper by increasing the quantity of SRB. But aeration would do harm to SRB through increasing oxygen.

Since SRB were the main microorganisms in this study, we obtained the OTUs of SRB and analyzed their species. The OTUs that belong to were Desulfovibrio, Desulforhabdus, Desulfomonile, Desulfococcus, Desulfobacca, Desulfurispora, Desulfotomaculum and Desulfosporosinus. Desulfovibrio, Desulforhabdus, Desulfomonile, Desulfococcus and Desulfobacca belong to Proteobacteria, while the others belong to Firmicutes. They have been reported to remove heavy metal from wastewater or polluted sediment (Cabrera et al. 2006, Fakhri Heravi et al. 2016).

\section{The correlation among bacterial community di- versity and copper concentration}

As the result mentioned above, the detail that how the BISC effected the relationship between bacterial community diversity and the removal rates of copper was also studied.

Diversity indices analysis. 952 OTUs were obtained from the 12 treated samples. The number of OTU for each sample is shown in Table 2. Based on the result of OTU, the alpha diversity was obtained 


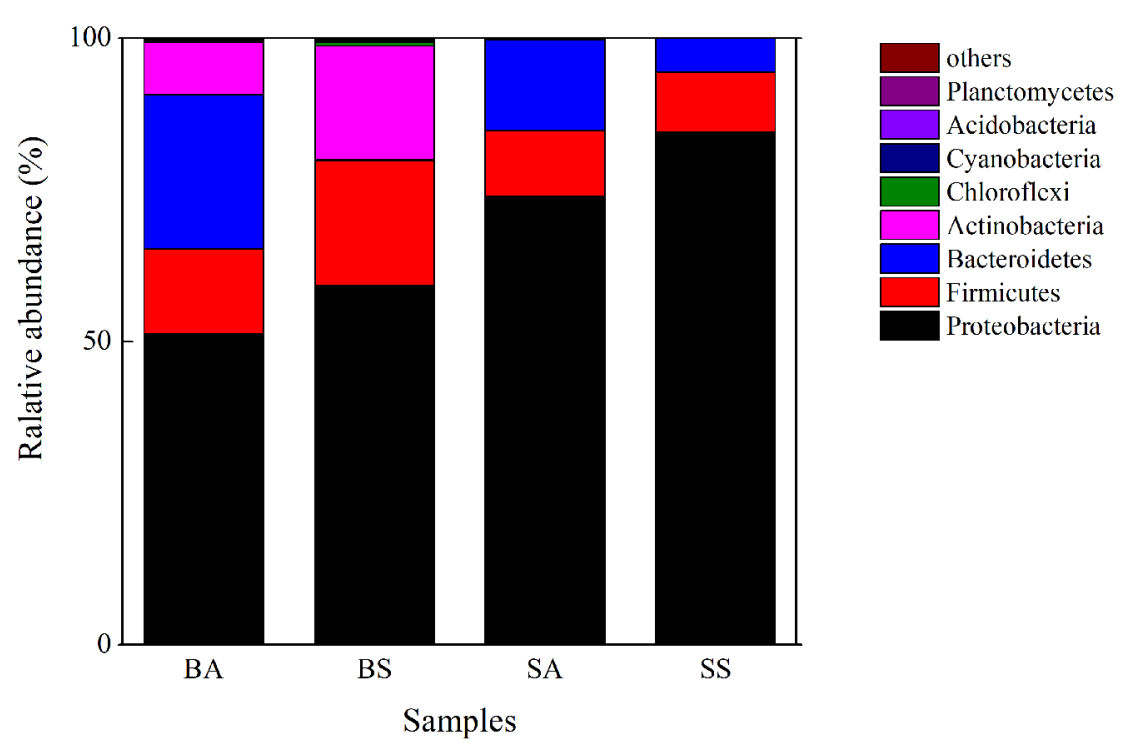

Fig. 2. Relative abundance (\% of total reads) of bacterial $16 \mathrm{~S}$ rRNA genes at the phylum level. For abbreviations, please see Fig. 1

via $R$. The alpha diversity is a result of the diversity analysis of species in an environment with one sample. In the experiment, the Shannon index was used as a measure to discuss the alpha diversity of the microbial community.

The calculation formula for the Shannon index showed that the increasing number of species in the community represented an increasing complexity of the bacterial community: the larger the Shannon index is, the higher the complexity of the bacterial community is. Shannon indexes indicated that (1) aeration groups were higher than settled groups; (2) groups with BISC were higher than those without BISC (Fig. 3). This showed that aeration affected the alpha diversity. It could be inferred from Fig. 1 and Fig.3 that although the bacterial community of aeration groups was more diverse, biological effectiveness of aeration groups did not decrease and consequently, aeration treatment was not beneficial to deal with copper via treatment of BISC. SRB belong to anaerobe microbiology and many studies have shown that the numbers of SRB in different depths varied in both sea and river sediments. Therefore, it could be inferred that oxygen might be one of the major factors that affected the vertical distribution of SRB.

Diversity indices calculated based on a cutoff of $97 \%$ similarity of $16 \mathrm{~S}$ rRNA sequences of 11,478 reads per sample. For abbreviations, please see Fig. 1. Additionally, the Kendall tau coefficient was used to define correlation among the alpha diversity indexes and copper concentration. Table II showed BCR1

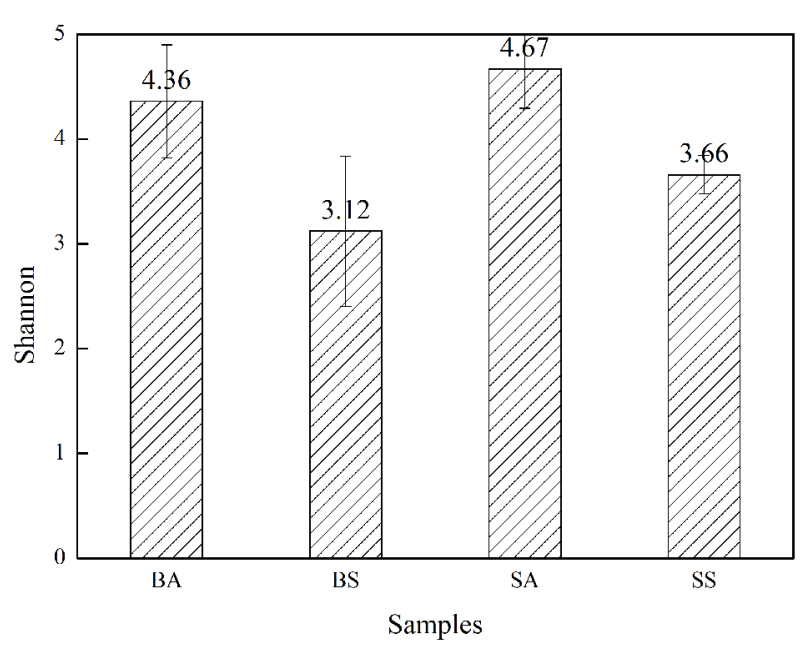

Fig. 3. Biological diversity index under different treatments via the Shannon index

and BCR2 both had correlation with alpha diversity, while BCR1 and alpha diversity were significant correlated and positive correlated.

\section{Beta diversity index analysis}

To investigate similarities and differences between different treatments, principal coordinate analysis (PCoA) was choosing to study OTUs. PCoA is a visualization method to study similarities and differences. This method is often used for the classification of a series of eigenvalues and eigenvectors and several main characteristic values are selected in the top. The principal coordinate of the 
TABLE II. CORRELATIONANALYSIS BETWEEN COPPER CONCENTRATION AND ALPHA DIVERSITY

\begin{tabular}{lccrrr}
\hline Samples & BCR1 & BCR2 & BCR3 & SUM & \multicolumn{1}{c}{ Total } \\
\hline P-value & $0.0080^{* *}$ & $0.0352^{*}$ & 0.5638 & 0.9913 & 0.6069 \\
tau & 0.2028 & 0.1525 & -0.0135 & -0.2007 & -0.0228 \\
\hline
\end{tabular}

$* \mathrm{P}<0.05 ; * * \mathrm{P}<0.01$

distance matrix can be found, which is measured by the beta diversity. In this test, the limited beta diversity analysis was used.

Fig. 4 showed the differences of the bacterial community. If the data points were close to each other, they would have little differences. If they were far apart, they would have considerable differences. The spots in the same color/shape originated from one sample. Fig. 4 showed that different groups were not close to each other, and each circle represented the same treatment. Fig.4(A) and Fig.4(B) showed that aeration and addition of BISC were all factors that affected the beta diversity. Fig.4(C) showed that different treatments did not have the same beta diversity. Different bacterial community structure resulted in different conversion rates and biological efficacy.

In the same way, Pearson test was used to define the correlation among beta diversity and copper concentration. Table III showed BCR1 and BCR2 both had correlation with alpha diversity, and they had the close correlation.

After obtaining both the tau coefficient and the $\mathrm{p}$-value via $\mathrm{R}$, it could be found that the correlation
TABLE III. CORRELATION ANALYSIS BETWEEN COPPER CONCENTRATION AND BETA DIVERSITY

\begin{tabular}{lccccc}
\hline Samples & BCR1 & BCR2 & BCR3 & SUM & Total \\
\hline P-value & $0.025^{*}$ & $0.030^{*}$ & 0.489 & 0.936 & 0.386 \\
r & 0.3062 & 0.3088 & -0.009 & -0.2627 & 0.0263 \\
\hline
\end{tabular}

$* \mathrm{P}<0.05$

analysis of the CAP index for beta diversity and copper concentration showed that BCR2 correlated with beta diversity of all treat, which prove the rationality of the study (Table IV).

TABLE IV. CORRELATION ANALYSIS BETWEEN COPPER CONCENTRATIONAND EXPERIMENTAL GROUPS

\begin{tabular}{llll}
\hline P-value & \multicolumn{1}{c}{ BCR1 } & \multicolumn{1}{c}{ BCR2 } & BCR3 \\
\hline Treat1 & 0.1478 & $0.0229^{*}$ & $0.0003^{* *}$ \\
Treat2 & $6.13 \mathrm{E}-11^{* *}$ & $4.78 \mathrm{E}-05^{* *}$ & 0.3112 \\
Treat3 & 0.0775 & $0.0148^{*}$ & $0.0002^{* *}$ \\
\hline
\end{tabular}

$* \mathrm{P}<0.05 ; * * \mathrm{P}<0.01$. Treat1: Blank and experimental test; Treat2: Aeration and settle treatments; Treat3: Four different treatments.

\section{DISCUSSION}

In this study, the biological efficacy of different forms of copper and the bacterial diversity and community structure analysis have been reported. Firstly,
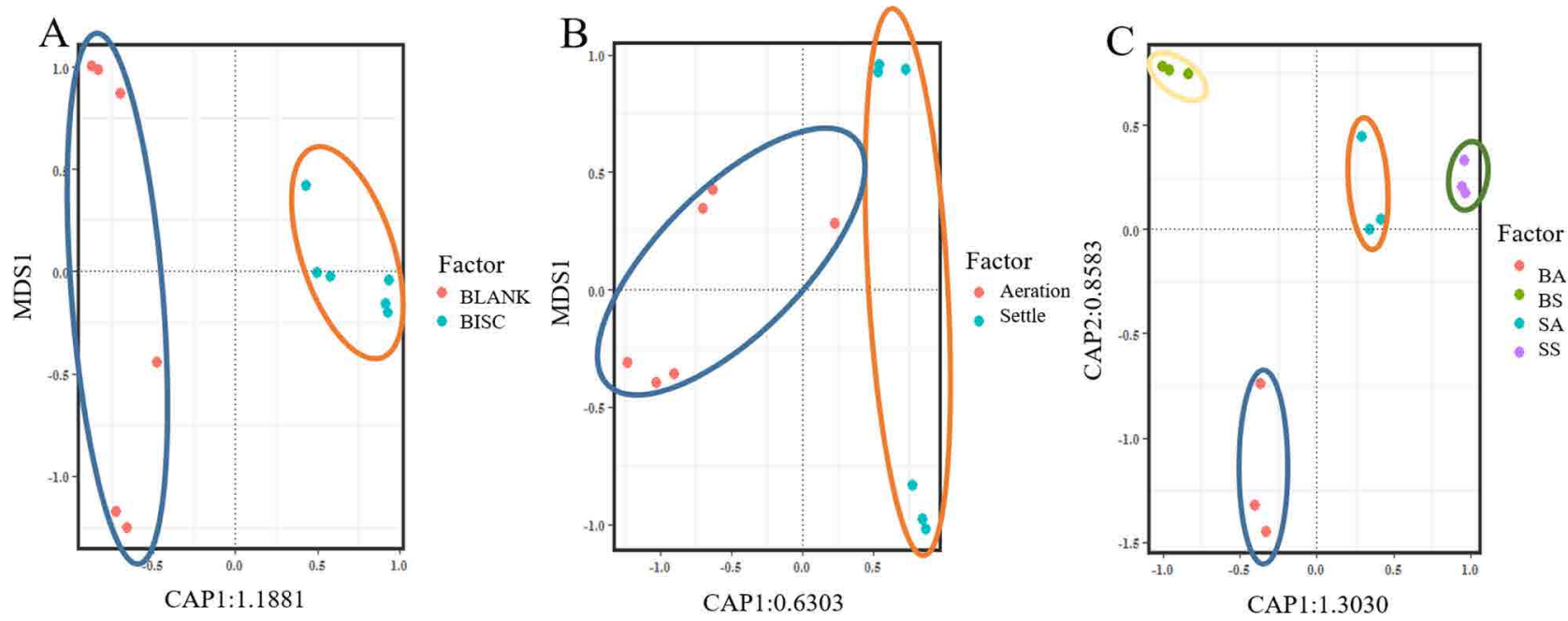

Fig. 4. Beta diversity analysis of samples. A: blank and experimental test (BLANK and BISC); B: Aeration and settle; C: four different treatments (BA, BS, SA and SS) 
copper-tolerant SRB were screened and named biological iron sulfide composites together with iron sulfide. Then, the article designed different treatments (aeration and non-aeration, adding BISC or not) to study a) the transformation of the form of copper geochemistry, b) the correlation between bacterial community and copper concentration. The efficiency of BISC remedies copper was also obtained. Our results state a theoretical basis for BISC to remedy heavy metals.

Through the analysis of geochemical forms of copper based on samples, it could be found that the BCR1 (weak acidic extraction state) in non-aeration samples were lower than that in the aeration samples, indicating that copper of non-aeration samples had lower biological efficacy. Meanwhile, the conversion rate of BCR1 and the increasing rate of BCR2 were both the highest in the non-aeration samples among all BISC samples. Fan reported that under the recovery effect of SRB, Cd can transform from the exchangeable state to the state of Fe-Mn oxides (extracted via the five-step Tessier sequential extraction method), leading to the decrease of Cd toxicity and bioavailability (Fan et al. 2008). In general, under the anaerobic condition, $\mathrm{SO}_{4}{ }^{2-}$ was reduced to $\mathrm{S}^{2-}$ as electron acceptor and the organism followed oxidative decomposition as electron donor under the action of SRB (White and Gadd 2000, Jong and Parry 2003 ). At the onset of aeration, $\mathrm{S}^{2-}$ was oxidized to $\mathrm{SO}_{4}{ }^{2-}$ and $\mathrm{SO}_{4}{ }^{2-}$ was reduced to $\mathrm{S}^{2-}$ when a sufficient amount of $\mathrm{O}_{2}$ was generated. Furthermore, sulfide will not inhibit the growth of SRB. Novel research suggested that $\mathrm{SRB}$ could tolerate a certain amount of dissolved oxygen; however, a high amount of dissolved oxygen could inhibit or even poison SRB. The non-aeration device used for the design of the experiment was not strictly anaerobic, but adopted the means of ventilation; therefore, oxygen could be assumed as a microenvironment (Dolla et al. 2006). The amount of dissolved oxygen increased after aeration, which might have inhibited the SRB metabolism. Consequently, it did not promote the transformation of geochemical forms of copper, relatively reducing the reduction state and oxidation state compared to non-aeration samples (Gao et al. 2017, $\mathrm{Si}$ and Qiao 2017). At the same time, the form of BCR2 was manganese oxide, which greatly reduced biological efficacy and provided the guarantee for the safe treatment of copper after biological iron sulfide composites removing copper. Many articles reported that SRB had a vertical distribution in sediments of $12-24 \mathrm{~cm}$ where bacterial abundances in general and SRB abundances in particular were both maximal; therefore, depth might also be the main reason that affects the heavy metal removal rate of SRB (Jiang et al. 2009, Varon-Lopez et al. 2014, Sun et al. 2016, de Oliveira et al. 2016).

16S rRNA gene analysis provided further information about the variation of total bacterial communities during the process that copper was removed by biological iron sulfide composites. Most of the obtained $16 \mathrm{~S}$ rRNA gene sequences were represented. At the end of the experiment, the bottom of the test tube with BISC present was darker than the surface layer and the middle layer. This could be considered as a downward migration of SRB, which was consistent with the antioxy genicity of SRB. Alpha diversity index was used to reflect the bacterial diversity of the samples. A comparison among the Shannon indexes suggests that the aeration process was higher, and the diversity was more complex (Guerrini et al. 2018, Yanar et al. 2017). The reason was that aerobic microorganisms formed the dominant group, and aeration was beneficial for their growth. The Kendall test showed the significant correlation between BCR1 and alpha diversity, which can be inferred that aeration not only increased alpha diversity but also the toxicity of copper since BCR1 does harm to human beings and environment.

The beta diversity among samples were also studied, and it suggested that the correlation among samples was poor, which meant that adding BISC and aeration would both affect the community structure of the sediment itself, resulting in differences between each other. At the same time, weak acidic extraction state and reduction state of copper were also obtained, which had an obvious correlation with beta diversity. In all samples, Proteobacteria were the dominant bacterial community. Of all sulfate reducers, the most abundant were Desulfurispora. The appropriate amount of dissolved oxygen could maintain the dominant bacteria of the SRB and maintain the balance between other anaerobic and aerobic bacterial groups. Many bacteria were synergistic and could degrade organisms more quickly and more efficiently; however, excessive dissolved oxygen destroyed the multi-flora balancing system and influenced the effect of organisms. Desulfovibrio had been used to treat acidic mine wastewater, heavy metal wastewater, and polluted sediment. At this point, SRB played an important role and not only SRB but also other microbes of the Proteobacteria might be involved in the removal of heavy metals due to the addition of BISC activating other indigenous SRB and other removing heavy metal microbiology. With the presence of nitrate, denitrifying bacteria compete with SRB for electron acceptor inhibiting sulfate reduction. 
Sulfate reduction is known as be an important process for the degradation of organic contaminants and it is a dominant anaerobic organic carbon transformation process in anoxic environments (Jorgensen 1982). In future studies, the relationship between the degradation of organic compounds and microbial growth as well as the relationship between the degradation of organic compounds and the removal of heavy metals can be investigated.

In this study, the effect of BISC on removing copper sediment was verified, and much further by the impact on indigenous microorganisms after adding BISC, so that it can provide application guidance for the emergent treatment of sudden heavy metal pollution accidents. One deficiency was that only the the diversity of bacterial communities with BISC at a certain depth were compared, and the further study will specifically focus on the vertical gradient distribution of BISC with different treatment methods. Currently, research on SRB has entered the stage of the functional gene, and many related functional genes have been reported to date; therefore, we can advance the research to the next step (Saad et al. 2017).

\section{ACKNOWLEDGEMENTS}

This work was supported by the Service Network Plan "Biological Resources Derived Library" about Strategic Biological Resources of Chinese Academy of Sciences (ZSYS-005) and National Natural Science Foundation of China (No. 51378013)

\section{CONFLICTS OF INTEREST}

The authors declare that there is no conflict of interest. This article does not contain any studies with human participants or animals performed by any of the authors.

\section{REFERENCES}

Abija F.A. and Nwankwoala H.O. (2018). Characterization of Aquifers in Parts of Abia State, Southeastern Nigeria. Acta Scientifica Malaysia. 2(1), 18-22.

Afzal M.N.I., Lawrey R., Anaholy M.S. and Gope J. (2018). A Comparative Analysis of The Efficiency and Productivity of Selected Food Processing Industries in Malaysia. Malaysian Journal of Sustainable Agriculture. 2(1), 19-28.
Angermeyer A., Crosby S.C. and Huber J.A. (2016). Decoupled distance-decay patterns between dsrA and 16S rRNA genes among salt marsh sulfate-reducing bacteria. Environmental Microbiology. 18 (1), 75-86, DOI: $10.1111 / 1462-2920.12821$.

Arshadullah M., Suhaib M., Baber R., Usama M., Zaman B., Mahmood I.A., Hyder S.I. (2017). Growth of Chenopodium quiona Wild under Naturally Salt Affected Soils. Malaysian Journal of Sustainable Agriculture. 1(1), 01-03.

Cabrera G., Perez R., Gomez J.M. Abalos A., and Cantero D. (2006). Toxic effects of dissolved heavy metals on Desulfovibrio vulgaris and Desulfovibrio sp. strains. J Hazard Mater, 135 (1-3), 40-46.

DOI: 10.1016/j.jhazmat.2005.11.058.

Caporaso J.G., Lauber C.L., Walters W.A., Berg-Lyons D., Huntley J., Fierer N. (2012). Ultra-high-throughput microbial community analysis on the Illumina HiSeq and MiSeq platforms. ISME J. 6 (8), 1621-1624.

DOI: 10.1038/ismej.2012.8.

Costa M.C., Martins M., Jesus C. and Duarte J.C. (2007). Treatment of Acid Mine Drainage by Sulphate-reducing Bacteria Using Low Cost Matrices. Water, Air, and Soil Pollution. 189 (1-4), 149-162. DOI: $10.1007 / \mathrm{s} 11270-007-9563-1$.

Crini G. (2006). Non-conventional low-cost adsorbents for dye removal: a review. Bioresour. Technol. 97 (9), 1061-1085.

DOI: 10.1016/j.biortech.2005.05.001.

De Oliveira J.F., Barboza E.G. and Benavente J. (2016). Nearshore Dynamics and Holocene Evolution of the Coastal Barrier South of the Santa Marta Cape, Southern Brazil. Journal of Coastal Research. (751), 437-441.

Deptuch A.B.H.J., Majoch A. and Ochal Z. (2011). Removal of heavy metals from electroplating plant wastewater with using sulfide ions produced by sulfate-reducing bacteria. Przemysl Chemiczny. 6 (90), 1000-1004.

Dolla A., Fournier M., and Dermoun Z. (2006). Oxygen defense in sulfate-reducing bacteria. J. Biotechnol. 126 (1), 87-100. DOI: 10.1016/j.jbiotec.2006.03.041.

Ebrahimi N., Gharibreza M., Hosseini M. and Ashraf M.A.(2017). Experimental study on the impact of vegetation coverage on flow roughness coefficient and trapping of sediment. Geology, Ecology, and Landscapes, 1(3), 167-172.

Edgar R.C., Haas B.J., Clemente J.C., Quince C., and Knight R. (2011). UCHIME improves sensitivity and speed of chimera detection. Bioinformatics. 27 (16), 2194-2200.

DOI: 10.1093/bioinformatics/btr381. 
Fan W., Jiang W., and Wang N. (2008). Changes of cadmium geochemical speciation in the process of soil bioremediation by Sulfate-Reducing Bacteria. Acta Scientiae Circumstantiae. 28 (11), 2291-2298.

Fude L., Harris B., Urretia MM., Beveridge T.J. (1994). Reduction of $\mathrm{Cr}(\mathrm{VI})$ by a Consortium of Sulfate-Reducing Bacteria (SRB III). Appl. Environ. Microbiol. 60 (5), 1525-1531.

Gao W., Baig A.Q., Ali H., Sajjad W. and Farahani M.R. (2017). Margin based ontology sparse vector learning algorithm and applied in biology science. Saudi Journal of Biological Sciences. 24 (1), 132-138. DOI: $10.1016 /$ j.sjbs.2016.09.001.

Gu J. and Zhang D. (2018). Analysis on Influencing Factors of Industrial Pollution Taking Zhejiang Province as An Example. Acta Scientifica Malaysia. 2(1), 14-16.

Guerrini G., Landi E., Peiffer K. and Fortunato A. (2018). Dry grinding of gears for sustainable automotive transmission production. Journal of Cleaner Production. $176,76-88$.

DOI: $10.1016 /$ j.clepro.2017.12.127.

Hausmann B., Knorr K.H., Schreck K., Tringe S.G., Glavina Del Rio T. and Loy A. (2016). Consortia of low-abundance bacteria drive sulfate reductiondependent degradation of fermentation products in peat soil microcosms. ISME J. 10 (10), 2365-2375. DOI: 10.1038/ismej.2016.42.

He H., Zhen Y., Mi T., Xu B., Wang G. and Zhang Y. (2015). Community composition and distribution of sulfate- and sulfite-reducing prokaryotes in sediments from the Changjiang estuary and adjacent East China Sea. Estuarine, Coastal and Shelf Science. 165, 75-85. DOI: 10.1016/j.ecss.2015.09.005.

Heravi M.R.F., Mesdaghinia A., Gharibi H., Jaafari J. and Hossein A. (2016). Performance evaluation of sulfate reducing bacteria in removing lead, chromium and nickel by anaerobic packed bed reactor. Desalination and Water Treatment. 59, 154-159.

DOI: $10.5004 /$ dwt.2016.1743.

Jalali K. (2000). The role of sulphate reducing bacteria in copper removal from aqueous sulphate solutions. Water Research. 34 (3), 797-806. DOI: 10.1016/s0043-1354(99)00194-3.

Jiang L., Zheng Y., Peng X., Zhou H., Zhang C. and Xiao X. (2009). Vertical distribution and diversity of sulfatereducing prokaryotes in the Pearl River estuarine sediments, Southern China. FEMS Microbiol. Ecol. 70 (2), 93-106.

DOI: $10.1111 / \mathrm{j} .1574-6941.2009 .00758$. x.

Johnson D.B. and Hallberg K.B. (2005). Acid mine drainage remediation options: a review. Sci. Total. Environ. 338 (1-2), 3-14.

DOI: $10.1016 /$ j.scitotenv.2004.09.002.
Jong T. and Parry D.L. (2003). Removal of sulfate and heavy metals by sulfate reducing bacteria in short-term bench scale up flow anaerobic packed bed reactor runs. Water Research. 37 (14), 3379-3389.

DOI: 10.1016/s0043-1354(03)00165-9.

Jorgensen B. (1982). Mineralization of organic matter in the sea bed the role of sulfate reduction. Nature. 296, 643-645.

Khan F., Khan M.I., Khan S., Zaman M.A.U., Rasheed H. and Khan A.R. (2018). Evaluation of Agronomic Traits for Yield and Yield Components in Wheat Genotypes with Respect To Planting Dates. Malaysian Journal of Sustainable Agriculture. 2(1), 7-11.

Kondo R., Mori Y. and Sakami T. (2012). Comparison of Sulphate-reducing Bacterial Communities in Japanese Fish Farm Sediments with Different Levels of Organic Enrichment. Microbes and Environments. 27 (2), 193199. DOI: $10.1264 /$ jsme2.ME11278.

Lu Z., Daxing X. and Hailun W. (2018). Two-Stage Cubature Kalman Filterand Its Application in Water Pollution Model. Acta Scientifica Malaysia. 2(1), 9-13.

Mogensen G.L., Kjeldsen K.U. and Ingvorsen K. (2005). Desulfovibrio aerotolerans sp. nov., an oxygen tolerant sulphate-reducing bacterium isolated from activated sludge. Anaerobe. 11 (6), 339-349.

DOI: 10.1016/j.anaerobe.2005.04.002.

Nawaz A., Arshad F. and Khurshid F. (2018). Evaluation of Low Cost Environment Friendly Natural Extracts for The Purification of Drinking Water. Acta Scientifica Malaysia. 2(1), 23-25.

Ong S.A., Toorisaka E., Hirata M. and Hano T. (2005). The Behavior of Ni(II), Cr(III), and Zn(II) in Biological Wastewater Treatment Process. Acta hydrochimica et hydrobiological. 33 (2), 95-103.

DOI: 10.1002 /aheh.200400559.

Pelikan C., Herbold C.W., Hausmann B., Mueller A.L., Pester M. and Loy A. (2016). Diversity analysis of sulfite- and sulfate-reducing microorganisms by multiplex dsrA and dsrB amplicon sequencing using new primers and mock community-optimized bioinformatics. Environmental Microbiology. 18 (9), 2994-3009. DOI: 10.1111/1462-2920.13139.

Pol L.W.H., Lens P.N.L., Weijma J., and Stams A.J.M. (2001). New developments in reactor and process technology for sulfate reduction. [Article; Proceedings Paper]. Water Science and Technology. 44 (8), 67-76.

Rahman S.A., Kahar A.A., Mansor A., Murni D.L., Hussin A., Sharifudin S.A., Hun T.G., Rashid N.Y.A., Othaman M.A. and Long K. (2017). Identification of potential indigenous microbe from local fermented vegetables with antimicrobial activity. Science Heritage Journal. 1(1), 01-03. 
Saad S., Bhatnagar S., Tegetmeyer H.E., Geelhoed J.S., Strous M. and Ruff S.E. (2017). Transient exposure to oxygen or nitrate reveals ecophysiology of fermentative and sulfate-reducing benthic microbial populations. Environmental Microbiology. 19 (12), 4866-4881. DOI: 10.1111/1462-2920.13895.

Samad N.S.A., Amid A.A., Jimat D.N. and Shukor N.A.A. (2017). Isolation and identification of halophilic bacteria producing halotolerant protease. Science Heritage Journal. 1(1), 07-09.

San N.O. and Donmez G. (2012). Biosorption of chromium (VI), nickel (II) and Remazol blue by Rhodotorula muciloginosa biomass. Water. Sci. Technol. 65 (3), 471-477. DOI: 10.2166/wst.2012.872.

Si L. and Qiao H. (2017). Performance of Financial Expenditure in China's basic science and math education: Panel Data Analysis Based on CCR Model and BBC Model. Eurasia Journal of Mathematics Science and Technology Education. 13 (8), 5217-5224. DOI: 10.12973/eurasia.2017.00995a.

Sun N., Zhang Y.C., Zhang W.G., Cheng E.L. and Liu Y.P. (2016). Heating Control of Heated Twin Radiosonde Humidity Sensor Based on Dmc. Polish Maritime Research. 23 (1), 52-58.

Ucar D., Bekmezci O.K., Kaksonen A.H. and Sahinkaya E. (2011). Sequential precipitation of $\mathrm{Cu}$ and $\mathrm{Fe}$ using a three-stage sulfidogenic fluidized-bed reactor system. Minerals Engineering. 24 (11), 1100-1105. DOI: 10.1016/j.mineng.2011.02.005.

Varon-Lopez M., Dias A.C.F., Fasanella C.C., Durrer A., Melo I.S. and Kuramae E.E. (2014). Sulphur-oxidizing and sulphate-reducing communities in Brazilian mangrove sediments. Environmental Microbiology. 16 (3), 845-855. DOI: 10.1111/1462-2920.12237.
Wang Q., Garrity G.M., Tiedje J.M. and Cole J.R. (2007). Naive Bayesian classifier for rapid assignment of rRNA sequences into the new bacterial taxonomy. Appl. Environ. Microbiol. 73 (16), 5261-5267.

DOI: 10.1128/AEM.00062-07.

Wen J., Yi Y. and Zeng G. (2016). Effects of modified zeolite on the removal and stabilization of heavy metals in contaminated lake sediment using BCR sequential extraction. Journal of Environmental Management. 178, 63-69. DOI: 10.1016/j.jenvman.2016.04.046.

White C. and Gadd G.M. (2000). Copper accumulation by sulfate-reducing bacterial biofilms. FEMS Microbiol. Ecol. 183, 313-318.

Xian X.F. (1987). Chemical partitioning of cadmium, zinc, lead, and copper in soils near smelter. Journal of Environmental Science and Health Part a-Environmental Science and Engineering and Toxic and Hazardous Substance Control. 22 (6), 527-541.

Xie Y., Li X. and Li F. (2013). Study on application of biological iron sulfide composites in treating vanadium-extraction wastewater containing chromium (VI) and chromium reclamation. Journal of Environmental Biology. 34, 301-305.

Yanar O., Gomec S., Topkara E.F., Solmaz G. and Demir I. (2017). The effect of plant quality on survival of lymantria dispar (lepidoptera: lymantriidae) larvae infected by bacillus thuringiensis berliner subsp kurstaki. Applied Ecology and Environmental Research. 15 (3), 837-847.

Yang Y., Xie Y., Li X., Zhou J. and Liu J. (2014). Microscopic characteristic of biological iron sulfide composites during the generation process and the association with treatment effect on heavy metal wastewater. Water Science and Technology. 70 (7), 1292-1297. 